\title{
POTENSI TEMPE KACANG HIJAU (VIGNA RADIATA L) HASIL FERMENTASI MENGGUNAKAN INOKULUM TRADISIONAL SEBAGAI PANGAN FUNGSIONAL
}

\author{
Siti Maryam \\ Jurusan Pendidikan Kimia, Universitas Pendidikan Ganesha \\ Singaraja, Indonesia \\ e-mail: titik_maryam@yahoo.co.id
}

\begin{abstract}
Abstrak
Tempe kacang hijau (Vigna radiata $L$ ) merupakan hasil proses fermentasi dari kacang hijau menggunakan inokulum tradisonal. Tujuan penelitian ini adalah menggunakan kacang hijau sebagai alternatif lain untuk bahan dasar pembuatan tempe dan juga untuk mengetahui adanya komponen antioksidan dan aktivitas antioksidan dalam tempe kacang hijau. Analisis komponen antioksidan dalam hal ini vitamin E (menggunakan HPLC) dan aktivitas antioksidan (metode PPH) bertutrut turut sebesar $8,83 \mathrm{ppm}$ dan 210,7372 mg/L. Adanya antioksidan dan aktivitas antioksidan merupakan potensi yang besar sebagai pangan fungsional.
\end{abstract}

Kata kunci : tempe kacang hijau, fermentasi, inokulum tradisional, vitamin E, aktivitas antioksidan

\section{Abstract}

Tempe mung bean (Vigna radiata $L$ ) is the result of fermentation of green beans using traditional inoculum. The purpose of this study was to use green beans as an alternative for the manufacture of tempeh and also to determine their antioxidant components and antioxidant activity in soybean green beans. The analysis of antioxidant components in this case was vitamin E (using HPLC) and antioxidant activity (method PPH) was at $8.83 \mathrm{ppm}$ and $210.7372 \mathrm{mg} / \mathrm{L}$. The presence of antioxidants and antioxidant activity is great potential as a functional food.

Keywords: mung bean tempeh, fermentation, traditional inoculum, vitamin E, antioxidant activity

\section{PENDAHULUAN}

Penganekaragaman pangan meru pakan salah satu program perbaikan gizi masyarakat, ini dilakukan karena tidak ada satupun bahan pangan yang memiliki kandungan gizi yang lengkap. Usaha penganekaragaman pangan dapat dilakukan dengan mencari bahan makanan yang baru atau bahan pangan yang sudah ada dikembangkan menjadi pangan yang beraneka ragam (Badan Ketahanan Pangan, 2010). Jamur yang tumbuh pada kedelai atau bahan dasar lainnya dapat menghidrolisis senyawa-senyawa komplek yang ada dalam kacang kedelai atau bahan lainnya seperti : karbohidrat, lemak dan protein menjadi senyawa sederhana berupa 
glukosa, asam lemak dan juga asam amino yang mana senyawa ini mudah dicerna oleh tubuh manusia, akibatnya berdampak dalam pemenuhan gizi keluarga (Alrasyid H., 2007).

Tempe merupakan salah satu produk makanan tradisional Indonesia dan dapat dinikmati oleh seluruh lapisan masyarakat. Makanan tersebut dibuat melalui proses fermentasi dari kacang kedelai atau kacang kacangan lainnya dalam waktu tertentu menggunakan jamur Rhizopus sp (Astawan, 2010 ). Jamur yang tumbuh pada kedelai atau bahan dasar lainnya dapat menghidrolisis senyawasenyawa komplek yang ada dalam kacang kedelai atau bahan lainnya seperti : karbohidrat, lemak dan protein menjadi senyawa sederhana berupa glukosa, asam lemak dan juga asam alfa amino yang mana senyawa ini mudah dicerna oleh tubuh manusia, akibatnya berdampak dalam pemenuhan gizi keluarga (Alrasyid H., 2007).

Mengkonsumsi tempe kedelai secara terus menerus adalah sangat penting, mengingat tempe mempunyai banyak kelebihan dibandingkan dengan bahan pangan lainnya yang berasal dari bahan dasar kedelai seperti tahu, saridele. Komponen gizi yang ada pada tempe antara lain berupa, antioksidan seperti : isoflavon yaitu genestein, daidzein, dan 8 hidroksi daidzein ; SOD (Super Oxide Dismutase) dan vitamin E (Maryam, 2009). Khasiat lain dari tempe adalah menaikkan kapasitas total antioksidan darah dan menurunkan kerusakan DNA pada tikus wistar akibat terpapar sinar ultraviolet (Maryam, 2010). Disamping itu, tempe juga dapat menurunkan kadar MDA (Malondialdehyde) pada tikus wistar yang teradiasi sinar ultraviolet (Maryam, 2011).
Akibatnya tidak disangsikan lagi jika tempe merupakan salah satu pangan fungsional, yaitu makanan yang apabila dimakan, tidak hanya mengenyangkan saja, akan tetapi dapat juga berfungsi meningkatkan kesehatan yang pada akhirnya dapat berfungsi sebagai perbaikan kesehatan manusia (Wijaya, 2002; Winarti, 2010).

Secara umum, masyarakat di Indonesia menggunakan bahan dasar kedelai dalam proses pembuatan tempe, padahal di lain pihak kedelai dapat juga digunakan sebagai bahan dasar membuatan makanan yang lain seperti tahu, sari kedelai, oncom, kecap, tauco dan lainnya. Akibatnya kedelai banyak digunakan dan tejadilah persaingan yang ketat dalam penyediaan bahan dasar untuk memproduksi bahan makanan yang berprotein tinggi dengan harga yang mudah dijangkau oleh masyarakat menengah kebawah. Adanya persaingan dalam penggunaan kedelai untuk produksi makanan, akan mengakibatkan timbulnya kelangkaan akan kedelai di masyarakat. Kedelai jarang ditemui dan juga harga kedelai meningkat dengan pesatnya. Keadaan ini akan berdampak terjadi krisis kedelai dan akibat lebih jauh pengerajin tempe kedelai tidak dapat memproduksi tempe kedelai lagi, seperti yang diberitakan di masmedia baru baru ini. Jika kondisi ini terus menerus terjadi akan berdampak lebih jauh masyarakat Indonesia yang memiliki tingkat ekonomi menengah kebawah akan memiliki gizi yang lebih buruk. Hal ini disebabkan makanan yang mereka makan tidak dilengkapi dengan lauk pauk yang berkualitas protein tinggi.

Bahan dasar pembuatan tempe dapat dilakukan dengan menggunakan berbagai macam kacang kacangan, seperti jagung, kacang tolo (benguk), lamtoro, 
kacang hijau (Vigna radiata), sehingga akan dihasilkannya tempe dengan nama yang berasal dari bahan dasarnya seperti tempe jagung, tempe lamtoro, tempe tunggak dan lain lainnya.

$$
\text { Ketersediaan kacang hijau }
$$

melimpah di Indonesia. Kacang hijau menduduki urutan ketiga dalam tanaman kacang-kacangan setelah kedelai dan kacang tanah (Agustine Susilowati, 2007). Permintaan terhadap komoditi kacang hijau termasuk stabil, karena penggunaannya berlanjut setiap hari dan sepanjang tahun. Jenis olahan kacang hijau antara lain kecambah kacang hijau, bubur kacang hijau, makanan bayi, kue dan pangan tradisional, minuman kacang hijau, tahu, sun, tepung hunkue, dan sayuran.

Penggunaan jenis kacang yang berbeda sebagai bahan dasar pembuatan tempe akan menghasilkan karakteristik fisikokimia dan sensori tempe yang berbeda. Hal ini disebabkan oleh perbedaan komposisi gizi terutama kandungan protein, karbohidrat dan lemak yang ada pada bahan dasar pembuatan tempe. sehingga tempe yang dibuat dari jenis kacang berbeda akan berbeda dari komponen gizi yang dimilikinya. Kacang hijau memiliki manfaat yang sangat penting untuk kesehatan, karena memiliki kandungan gizi yang cukup baik. Dalam 100 gram kacang hijau mengandung karbohidrat sebesar $62,5 \mathrm{gr}$; protein 22,2 gr ; lemak 1,5 gr ; vitamin A 9 IU ; vitamin B1 150-400 IU dan juga mineral seperti kalsium, belerang, mangan dan besi. Komponen ini diperlukan dalam tumbuh kembang dan juga menjaga kesehatan tubuh manusia.

Pemanfaatan kacang hijau sebagai tempe kacang hijau akan dapat menghasilkan suatu produk makanan baru yang kaya akan protein dan juga kaya akan antioksidan yang disebabkan adanya senyawa tersebut dalam bahan dasarnya (Kakati $P$ et al, 2010, A.C.Oburuoga and J.U.Anyika, 2012, Kamariah, 2013). Akibatnya tempe kacang hijau merupakan pangan fungsional, suatu makanan yang apabila dimakan tidak hanya mengenyangkan tetapi juga akan berdampak positif pada tubuh manusia karena dapat meredam radikal bebas (Wijaya, 2007). Disamping itu ketergantungan akan kedelai dapat teratasi. Keadaan ini akan mengakibatkan terjadinya effisiensi produksi tempe yang meningkat karena tidak semata mata untuk memproduksi tempe tergantung dari adanya kedelai sebagai bahan dasar. Kondisi ini akan mendorong masyarakat dalam pemenuhan kebutuhan gizi serta dihasilkannya bahan makanan tempe yang beraneka ragam dengan nilai tambah berupa pangan fungsional, yang disebabkan oleh adanya komponen antioksidan yang terdapat dalam tempe termodifikasi sehingga nantinya keadaan gizi buruk tidak akan terjadi di masyarakat, disamping program diversifikasi

\section{METODE}

Untuk mengetahui adanya potensi tempe kacang hijau sebagai pangan funsional, dilakukan analisa tentang komponen antioksidan yang ada dalam tempe kacang hijau (Vigna radiata $L$ ). Analisis meliputi kadar vitamin $E$ dan aktivitas antioksidan. Sampel penelitian dalam hal ini berupa tepung tempe kacang hijau (Vigna radiata $L$ ) yang dibuat dari tempe kacang hijau. Proses pembuatan tempe kacang hijau :

Ada beberapa proses dalam pembuatan tempe kacang hijau antara lain : 
(a) Bersihkan kacang hijau; (b) Rendam kacang hijau dengan air asam cuka $\mathrm{pH} 5$ selama 12 jam; (c) Bersihkan dan rendam dalam air selama 12 jam; (d) Rendam dalam air mendidih selama 15 menit; (e) Tiriskan dan siap untuk difermentasi dengan inokulum tradisional (daun waru) dan inokulum serbuk (raprima); Fermentasi selama 48 jam dan dihasilkan tempe kacang hijau

Setelah dihasilkannya tempe kacang hijau , maka dilajutkan dengan proses pembuatan serbukdengan temperatur $80^{\circ} \mathrm{C}$. Tepung inilah yang dianalisis kandungan antioksidan dan aktivitas antioksidan.

Penentuan kadar vitamin E pada tempe kacang hijau ( Vigna radianta L) yang difermentasi dengan menggunakan inokulum tradisional dilakukan dengan menggunakan uji AOAC (2000) 43.087 43.096. Dan aktivitas antioksidan (metode $\mathrm{DPPH}$ ) dengan menggunakan alat spektrofotometer double beam shimadzu. Prosedur kerja yang dilakukan pada analisis ini adalah :1) Larutan buffer asetat $100 \mathrm{mM}(\mathrm{pH}$ 5.5) sebanyak 1,5 ml masukkan dalam tabung reaksi ; 2) Kemudian tambahkan 2,805 ml etanol dan $0,15 \mathrm{ml}$ senyawa radikal bebas $\mathrm{DPPH} 3 \mathrm{mM}$ dalam metanol lalu divortex ; 3) Sebanyak 0,045 ml larutan sampel dimasukkan ke dalam tabung reaksi divortex dan disimpan dalam ruang gelap suhu kamar selama 20 menit : 4) Absorbansi dibaca pada panjang gelombang $517 \mathrm{~nm}$; 5) Untuk blangko sampel digunakan $0,045 \mathrm{ml}$ aquades sebagai pengganti sampel ; 6) Untuk blanko alat gunakan $0,045 \mathrm{ml}$ aquades sebagai pengganti sampel dan DPPH diganti dengan metanol ; 7) Penurunan absorbansi pada larutan yang berisi sampel menunjukkan adanya aktivitas antioksidan ; 8) Sebagai standar digunakan asam askorbat dan hasil akhir dinyatakan dengan $\mu \mathrm{g} / \mathrm{g}$ AEAC (ascorbat acid equivalen antioxsidant capacity).

\section{HASIL DAN PEMBAHASAN}

Kadar vitamin $E$ yang ada pada tempe kacang hijau (Vigna radiata $L$ ) hasil fermentasi menggunakan inokulum tradisional adalah, sebesar 8,83 ppm dan aktivitas antioksidan sebesar 210,7372 $\mathrm{mg} / \mathrm{L}$. Adanya kandungan vitamin $\mathrm{E}$ dan aktivitas antioksidan pada tempe kacang hijau (Vigna radiata $L$ ) ini disebabkan oleh aktivitas inokulum tradisional yang digunakan pada proses fermentasi. Inokululum tradisional, yang berupa campuran dari beberapa rhizopus seperti Rhizopus oligosporus, Rhizopus oryzae, Rhizopus stolonifer dan Rhizopus arrizus, yang terdapat dalam daun waru. Rhizopus yang ada memiliki kemampuan mendegradasi atau hidrolisis komponen makromolekul seperti karbohidrat, lemak dan protein yang ada dalam kacang hijau, menjadi senyawa senyawa kecil atau monomernya dan juga dihasilkannya metabolit sekumder melalui proses metabolisme an aerob, akibatnya pada tempe kacang hijau (Vigna radiata $L$ ) akan terdapat atau dihasilkannya vitamin $\mathrm{E}$ atau alfa tokoferol Vitamin E merupakan salah satu senyawa organik yang dapat bertindak sebagai antioksidan. Berfungsinya vitamin E sebagai antioksidan, disebabkan karena adanya ikatan rangkap yang ada pada struktur vitamin E. Adanya ikatan rangkap ini, akan mengakibatkan terjadinya delokalisasi elektron dan pada akhirnya akan memiliki kemampuan untuk menangkap atau meredam radikal bebas yang dihasilkan atau terbentuk akibat pada proses stres oksidatif. Kemampuan menangkap radikal bebes inilah yang 
menyebabkan suatu zat yang mengandung vitamin $\mathrm{E}$ akan bersifat sebagai antioksidan atau peredam radikal bebas.

Setiap antioksidan akan memiliki kemampuan untuk meredam radikal bebas yang bervariasi. Banyaknya radikal bebas yang dapat diredam, sangat tergantung dari aktivitas antioksidannya, yaitu kemampuan dari senyawa untuk menangkap radikal bebas. Semakin besar aktivitas antioksidannya, maka kemampuan untuk meredam radikal bebas juga akan semakin tinggi.

Terdapatnya antioksidan dan aktivitas antioksidan pada tempe kacang hijau menandakan bahwa tempe kacang hijau dapat digunakan sebagai pangan fungsional, yaitu suatu pangan yang apabila dimakan, tidak hanya menge nyangkan saja akan tetapi juga dapat bertindak sebagai antioksidan yaitu zat yang dapat menangkap radikal bebas atau spesi reaktif yang tanpa disadari terus menerus terjadi, baik akibat metabolisme secara normal yang terjadi maupun akibat respon terhadap pengaruh luar tubuh seperti polusi lingkungan, dampak sinar ultraviolet maupun akibat lainnya.

Vitamin $E$ merupakan antioksidan sekunder karena tidak dihasilkan dalam tubuh. la dapat diperoleh dari makanan yang dikonsumsi atau dapat diperoleh dari luar tubuh. Adanya antioksidan ini akan mampu mencegah terjadinya reaksi berantai yang terjadi dalam tubuh. Vitamin E yang terdapat pada tempe kacang hijau, merupakan hasil metabolisme atau pembentukan selama proses fermentasi yang melibatkan kerja dari mikroorganisme berupa campuran Rhizopus $s p$. hal ini dapat dijelaskan karena bahan dasar yang digunakan berupa kacang hijau (Vigna radiata $L$ ) tidak mengandung vitamin $\mathrm{E}$ (tabel komposisi bahan makanan). Rhizopus yang terdapat dalam inokulum tradisional yang terdapat dalam daun waru, merupakan campuran dari Rhizopus oligosporus, Rhizopus oryzae, Rhizopus stolonifer dan Rhizopus arrizus. Masing masing Rhizopus sp mengandung enzim tertentu sehingga tempe yang dihasilkan dari proses fermentasi merupakan makanan yang berpotensi mengandung gizi dan nilai cerna serta antioksidan yang baik.

Aktivitas antioksidan adalah kemampuan dari suatu bahan, dalam hal ini tempe kacang hijau untuk bertindak atau berfungsi menangkap radikal bebas akibat reaksi metabolisme atau keadaan lingkungan. Semakin besar komponen antioksidan yang ada maka memiliki kemamuan semakin tinggi sebagai penangkal radikal bebas semakin besar, akibatnya radikal bebas yang ada dalam tubuh akan semakin sedikit, karena sudah dinetralkan oleh antioksidan yang ada. Ada korelasi antara jumlah radikal bebas yang ada dalam tubuh dengan kesehatan seseorang. Semakin banyak radikal bebas yang ada dalam tubuh, maka kesehatan orang tersebut semakin rendah dan pada akhirnya ia menjadi sakit. Adanya radikal bebas dalam tubuh manusia akan memicu proses penumpukan atau pengendapan kolesterol dan komponen lainnya dalam aliran darah manusia (Abdel Fattah , 2010) Oleh sebab itu disarankan untuk mengkonsumsi makanan yang kaya akan antioksidan sehingga memiliki kemampuan yang besar dalam penanggulangan suatu penyakit akibat radikal bebas seperti penyakit Diabetes Melitus, degeneratif dllnya.

Saat ini, kejadian pemanasan global yang semakin meningkat, seperti diketahui terjadi penipisan lapisan ozon 
dipermukaan bumi, sehingga kemungkinan radiasi sinar ultraviolet yang jatuh ke permukaan bumi akan semakin besar karena penghalang sudah semakin menipis. Akibatnya manusia yang merupakan salah satu mahluk hidup yang ada dibumi, ada kecendrungan terdampar radikal bebas akibat sinar ultraviolet akan semakin tinggi. Sudah saatnya manusia untuk melindungi diri dengan mengkonsumsi antioksidan dalam makanannya.

Setiap saat manusia dalam menjaga kelangsungan hidupnya dengan cara konsumsi makanan. Asupan makanan yang setiap hari dilakukan akan berdampak pada pemenuhan kebutuhan tubuh akan komponen makromolekul dan juga merupakan modal dasar dari segala aktivitas yang akan dilakukan. Dapat dibayangkan jika manusia dalam kesehariannya tidak mengkonsumsi makanan, maka sudah barang tentu tidak ada energi yang dihasilkan. Akibat lebih jauh maka manusia tidak akan dapat beraktivitas dan juga tidak akan dapat tumbuh kembang, sesuai dengan sifat hakiki dari mahluk hidup.

Pemenuhan konsumsi keseharian manusia, tidak terlepas dari komponen gizi yang seimbang dan komponen aktif yang ada dalam makanan seperti antioksidan, sehingga manusia menjadi sehat dan dapat beraktivitas dengan maksimal.

Antioksidan yang potensial dan murah harganya adalah tempe, dalam hal ini tempe kacang hijau (Vigna radiata $L$ ).

Adanya konsumsi tempe yang merupakan makanan tradisional indonesia sangat diperlukan saat ini. Disamping murah harganya, sehingga seluruh lapisan masyarakat dapat memilikinya dan dilain pihak merupakan makanan yang sangat bermanfaat untuk menjaga kesehatan tubuh. Memang tempe yang terkenal adalah tempe kedelai, akan tetapi dengan melihat kemungkinan bahan kacang lain dapat berpotensi digunakan menjadi tempe, maka mengkonsumsi tempe kacang hijau (Vigna radiata $L$ ) merupakan suatu kebutuhan yang sangat diperlukan oleh manusia karena mengandung komponen antioksidan atau bioaktif yang potensial.

Budaya untuk konsumsi tempe kacang hijau (Vigna radiata $L$ ) saat ini harus terus disosialisaikan karena tempe yang terbuat dari bahan dasar kacang hijau (Vigna radiata $L$ ) belum banyak dilakukan. Masyarakat memanfaatkan kacang hijau baru sebatas membuat bubur kacang hijau, saridele dan juga tahu.

\section{Ucapan terima kasih}

Terima kasih yang sebesarnya diucapkan kepada laboratorium biokimia $F$ MIPA Undiksha, yang telah memberikan fasilitas untuk melakukan penelitian. Demikian juga pada laboratorium teknologi pertanian UNUD tempat melakukan analisis komponen antioksidan maupun aktivitas antioksidan.

\section{DAFTAR PUSTAKA}

Abdel Fattah. 2010. The Effects of Dietary Suplementation with Barley Seeds and Hay on Ochratoxin A Toxicity using lactating Egyptian Goats, J of American science. (6) 9

A.C. Oburuoga and J.U.Anyika. 2012. Nutrient and Antinutrient Composition of Mungbean (Vigna radiata L), Acha (Digitaria exilis) and Crayfish (Astacus fluviatilis) Flour, Fakistan Journa of Nutrition 11(9) : 743-746, ISSN 16805194 
Agustine Susilowati et al. 2007. Differences in Proscess Scale on Preparation of VegetableBroth of Mung Beans (Phaseolus radiatus $L$ ) Through Brine Fermentation Using Inoculum of Rhizopus- $\mathrm{C}_{1}$, International Confrence on Chemical Sciences (ICCS 2007). Yogyakarta

Alrasyid H. 2007. Peranan isoflavon tempe kedelai, fokus pada obesitas dan komorbil, Majalah kedokteran nusantara, Vol 40, No 3

Astawan. 2009. Sehat dengan Hidangan Kacang dan Biji-Bijian, Cetakan 1. Penebar Swadaya. Jakarta. hal 122131.

Kakati $P$ et al. 2010. Effect of Traditional Methode of Processing on The Nutrient Contents and Some Antinutritional Factor in Newly Developed Cultivars of Green Gram (Vigna radiata $L$ ) Wilezek and black gram (Vigna mungo L) Hepper of Assam India, International Food Research. 17: 377-384

Ketahanan Pangan. 2010. Kebijakan Umum Ketahanan Pangan. Jakarta

Kamariah Lung. 2013. Comparison of aminobutyric acid (GABA) content and antioxidant activities of conventional soybean tempeh and new generation mung bean tempeh produced using Rhizopus sp,2 nd International Confrence and exhibition

Maryam Siti. 1997., Pengaruh Konsentrasi Inokulum campuran (Rhizopus oligosporus dan Rhizopus oryzae) dan Lama Fermentasi Terhadap Kadar Asam Fitat, Mutu Organoleptik dan Protein Efficiency ratio pada Tempe Kedelai. Tesis Program Studi IImu Kedokteran Dasar. Program
Pascasarjana Universitas Airlangga Surabaya.

Maryam Siti. 2009. Analisa kualitatif komponen biaktif pada tempe yang difermentasi dengan menggunakan inokulum campuran Rhizopus oligosporus dan Rhizopus oryzae

Maryam Siti. 2010. Pengaruh Tempe Kedelai Terhadap Kadar MDA Pada Tikus Yang Teradiasi Sinar Ultraviolet.

Maryam Siti. 2011. Tempe Reduce DNA Damage In Rats Irradiated With Ultravolet Ray, E Jurnal Fak Kedokteran UNUD, Volume 1

Wijaya H. 2007. Pangan fungsional dan kontribusinya bagi kesehatan. seminar online charisma ke 2.

Winarti S. 2010. Makanan Fungsional, Cetakan ke 1, Graha IImu. Yogyakarta 